\title{
The Comparison of A HUMAN BEING IS A PLANT Metaphor between the English and Polish Language
}

\author{
Sylwia Filipczuk-Rosińska ${ }^{1, *}$ \\ ${ }^{1}$ Department of Foreign Languages, Polish Air Force Academy, Dęblin, Poland \\ *Correspondence: Sylwia Filipczuk-Rosińska, Polish Air Force Academy, Dęblin, ul. Dywizjonu 303 no. 35, 08 \\ -521, Poland. Tel: 48-605-172-940. E-mail: s.filipczuk@wsosp.pl
}

Received: January 19, 2016

Accepted: January 27, 2016

Online Published: January 31, 2016

doi:10.5430/wjss.v3n1p15

URL: http://dx.doi.org/10.5430/wjss.v3n1p15

\begin{abstract}
The following paper focuses on the conceptual structural metaphor A HUMAN BEING IS A PLANT (Krzeszowki 1997), which is related to the Great Chain of Being metaphor (Kövecses 2002). The assumption being that the source domain of PLANTS is well-grounded in people's everyday experience, it is well-represented in cognitive storage structures such as categories, frames or Idealized Cognitive Models. Therefore, it was assumed that establishing the set of correspondences across the domains in order to re-create the mapping process should conceptually not pose considerable difficulty. The primary objective of the undertaken research was to compare a sample of formulated elaborations of the metaphor between the English and Polish language on the basis of data in the form of sentences collected from respective online language corpora. This comparison was feasible due to the level of background knowledge possessed by the authoress as a native speaker of Polish and second language learner of English.
\end{abstract}

Keywords: metaphor, target domain, source domain, elaboration, lexeme, L1, L2, equivalent

\section{Theoretical Framework and Literature Review}

Traditionally, metaphor was not associated with cognition and hence not considered a conceptual mechanism. On the contrary, in Aristotle's so-called "classic view" it was believed to amount to nothing more than " (...) giving the thing a name that belongs to something else; the transference being either from genus to species, or from species to genus, or from species to species, on the grounds of analogy" ( Poetics 230). Similarly, more contemporary scholars such as Paul Ricoeur (1975) or John Searle (1979) advocate the "decorative approach" according to which metaphor is a purely linguistic phenomenon. Therefore, it is confined to enriching the meaning of poetry and rhetoric not everyday discourse conducted between speakers of a given language in a given situational context, be it in the oral or written form.

The notion of metaphor acquired a cognitive dimension with the development of the "Conceptual Metaphor Theory" outlined by Lakoff and Johnson (1980) in their seminal book entitled Metaphors We Live By. It began to be perceived as a cognitive mechanism that governs people's understanding of the world(Note 1). Consequently, Lakoff (1992: 1) maintains that metaphor does not originate from language but from our conceptualisation of one mental domain(Note 2) in terms of another". The conceptualisation in question occurs during a cognitive process called mapping " (...) whereby one experiential domain is partially mapped onto a different experiential domain, the second domain being partially understood in terms of the first one" Barcelona (2002: 146). This peculiar transference of meaning is performed at the superordinate(Note 3) level of a category (Lakoff 1992) from the more concrete well-structured source domain (e.g. PLANTS, JOURNEY, CONTAINER) onto the more abstract not instantly comprehended target domain (e.g. HUMAN BEINGS, EMOTIONS, TIME).

The most extensively researched structural(Note 4) metaphor is LOVE IS A JOURNEY, in which the well-defined structure of the JOURNEY domain is mapped onto the elusive concept of LOVE, which belongs to the domain of EMOTION. Lakoff (1992: 5) provides the following set of correspondences:

- The lovers correspond to travellers.

- The love relationship corresponds to the vehicle. 
- The lovers' common goals correspond to their common destinations on the journey.

- Difficulties in the relationship correspond to impediments in travel. (ibid.)

In consequence, Lakoff's analysis allows us to accurately comprehend concepts conveyed in sentences such as: Our relationship is a dead end. More specifically, we do not wrongly assume that one of the lovers is terminally ill and will die soon, but we make the correct presupposition that in a way the lovers' relationship reached the end of their destination, which simply means that it will most likely ultimately result in a break-up.

Another well-structured metaphor applied by Lakoff and Johnson (1989) in the analysis of proverbs is the Great Chain of Being or the Chain of Being. According to the Encyclopeadia Britannica (2015), it is a well-entrenched conception concerning nature and the universe found in the philosophy of ancient Greek Neoplatonists, the European Renaissance, and the $17^{\text {th }}$ and early $18^{\text {th }}$ centuries(Note 5 ). One of its most basic principles of continuity stresses interrelations between animate and inanimate entities, which form constituent chain links. Kövecses (2002: 126) claims that each chain link is distinguished by particular attributes and behaviour, e.g. humans possess rational thought, whereas plants - certain biological properties. Consequently, it can be stated that the interconnection results in sharing attributes typical between the links. Kövecses (ibid.) conceptualizes the Great Chain of Being as follows:

HUMANS: Higher-order attributes and behaviour (e.g. thought, character).

ANIMALS: Instinctual attributes and behaviour.

PLANTS: Biological attributes and behaviour.

COMPLEX OBJECTS: Structural attributes and functional behaviour.

NATURAL PHYSICAL OBJECTS: Natural physical attributes and natural physical behaviour.

Conversely, Krzeszowski (1997: 68) extends the Chain by adding GOD at the top position, which is consistent with the Jewish-Christian tradition expressed in the Old Testament and characteristic of the Catholic religion:

GOD

\section{HUMANS}

ANIMALS

PLANTS

\section{INORGANIC THINGS}

While analysing both hierarchical variants of the Chain and noticing the inherent interconnections, it becomes evident that mappings can occur downward as well as upward. Accordingly, Krzeszowski (ibid.) formulates the metaphor that is the focus of the following paper, namely: <A HUMAN BEING IS A PLANT>.

\section{Reasons for Research and Hypotheses}

There are three underlying reasons for the selection of this particular metaphor for research. Firstly, having familiarised myself with a number of articles, including Shozo Fujita's (1976) The Metaphor of Plant in Jewish Literature of the Intertestamental Period, I drew a conclusion that PLANTS as the source domain are predominantly researched within the framework of the Bible, especially the Old Testament and not contemporary meanings. Accordingly, a question that arises is whether this source domain is used to comprehend HUMAN BEINGS nowadays or whether it has become obsolete. Secondly, the rich set of correspondences in the structural metaphor LOVE IS A JOURNEY, its numerous linguistic realizations and more detailed instances - the so-called elaborations (e.g. STOPPING TO LOVE ONE'S PARTNER IS REACHING THE END OF ONE'S DESTINATION) led to a working hypothesis that the metaphor A HUMAN BEING IS A PLANT might be equally productive in terms of research data. As a result, it prompted me into developing such a network for the metaphor under analysis. Finally, being a native speaker of Polish and having graduated from English studies, my objective was to compare data obtained in my L1 and L2. The question that posed itself was whether the primary metaphor A HUMAN BEING IS A PLANT could be realized by means of lexical equivalents in both L1 and L2. If yes, then another issue subject to consideration was whether sentences including these equivalents in the form of noun or verb phrases could be grouped with regard to similar negative or positive denotation and assigned a common metaphorical elaboration for both languages. Finally, if the scope of meaning displayed some similarity, then what the source of this similarity might be. 


\section{Methodology}

The research method adopted by the authoress for the purpose of this paper can be summarized in the following stages:

STAGE 1: Developing a set of ontological correspondences between the source domain of PLANTS and the target domain of HUMAN BEINGS.

STAGE 2: On the basis of established mappings, compiling a limited list of lexemes equivalent between Polish and English.

STAGE 3: Collecting research data from a chosen Polish and English online corpus according to lexemes equivalent between languages.

STAGE 4: Grouping corresponding sentences with regard to their positive and negative denotation.

STAGE 5: Formulating elaborations of the primary metaphor HUMAN BEINGS ARE PLANTS within groups of positive and negative denotations.

STAGE 6: Comparing Polish and English elaborations to specify cross-cultural similarities.

\subsection{Developing a Common Set of Correspondences}

The rationale behind developing the common set of correspondences between the source domain of PLANTS and the target domain of HUMAN BEINGS was to reflect various mappings, which constitute the metaphor as a whole. The development was facilitated by referring to the background knowledge as regards both domains stored in one's long-term memory in the following conceptualized cognitive structures: frames(Note 6), categories - both superordinate and subordinate as well as Idealized Cognitive Models (ICMs)(Note 7). Additionally, it proceeded in accordance with the cognitive premise that the more tangible and grounded in experience source domain is mapped onto the more abstract target domain. The direction of the process is indicated by means of an arrow in Table 1 below.

Table 1. Common set of Metaphorical Correspondences within the Primary Metaphor A HUMAN BEING IS A PLANT

\begin{tabular}{ll}
\hline SOURCE DOMAIN & TARGET DOMAIN \\
PLANTS & HUMAN BEINGS \\
\hline vegetation & life \\
planting & inseminating \\
growing & developing \\
sick plant & sick person \\
withering & ageing, dying \\
fertilising & stimulating development \\
ripening & maturing \\
roots & human being's background \\
destroying a plant & disposing of human beings \\
\hline
\end{tabular}

\subsection{Selecting Lexemes for Analysis}

Subsequently, several correspondences were chosen, the assumption being their relatively high potential linguistic productivity. On their basis, lexemes were found in Polish and English with reference to the linguistic knowledge possessed by the authoress as a native speaker of Polish and acquired as an L2 speaker of English. Bearing in mind that the following paper does not constitute an extensive study but is an indication of a research issue, only a number of representative lexemes were chosen. Furthermore, the sample in question was limited to verbs and nouns since metaphorical elaborations are formulated within syntactic units of NPs and VPs(Note 8). 
Table 2. Selected Lexemes Consistent with the Established Mappings

\begin{tabular}{lll}
\hline Mapping & English Lexemes & Polish Lexemes \\
\hline 1. vegetation $\rightarrow$ life & vegetation & wegetacja \\
2. growing $\rightarrow$ developing & to vegetate & wegetować \\
& to grow & rosnąć \\
& to bud & rozkwitać \\
& a bud & pączek \\
3. withering $\rightarrow$ becoming sick, ageing, dying & to blossom & rozkwitać \\
4. ripening $\rightarrow$ maturing & to bloom & kwitnąć \\
5. destroying a plant $\rightarrow$ disposing of human beings & to wither & więdnąć \\
& to ripen & dojrzewać \\
\end{tabular}

\subsection{Source of Research Data}

Selected lexemes grouped in Table 2 were used to obtain research data. The sources of data were two representative online language corpora. Namely, Polish sentences were chosen from Korpus Języka Polskiego PWN, which includes 100 million words obtained from authentic materials such as newspapers, books, leaflets, advertisements, manuals and regulations. As editors emphasize, it differs from corpora available in other languages since the number of literary texts is more pronounced. The reason for it being the distinctive Polish tradition of referring to literature as a criterion of linguistic accuracy. As far as English is concerned, data was gathered from The British National Corpus originally created by Oxford University Press, which also includes 100 million words in a wide variety of registers such as spoken, academic, medical and many other.

\section{Results}

Results presented below are a limited sample of collected examples. They are divided into elaborations with positive and negative denotations. Lexemes of interest are underlined. English translations of Polish sentences are provided in brackets. In some cases, no English examples with lexemes chosen in Table 2 were found, which entails that not all lexemes from the domain of PLANTS can be applied to HUMANS.

\subsection{Elaborations with Positive Denotation}

\section{ACQUIRING BEAUTY BY PEOPLE IS FLOWERING OF A PLANT}

a) Those kids are really blooming.

She blossomed overnight, going from stinkweed to rose with but one sip of potion.

b) Ubogie dziewczęta w cerowanych pończochach rozkwitaja w ciągu tygodnia, zamieniając się w lwice.

English translation: [Poor girls in darned stockings blossom in a week changing into lionesses]

\section{DEVELOPING IS BLOSSOMING}

a) In the Lyttelton, it's such a thrill to see Alan Bennett blossom in another line of work, by which I mean a full-length piece like The Madness of George III.

b) Zdaniem Murraya, ludzki geniusz najlepiej rozkwita w kulturze (...).

English translation: [According to Murray, human genius blossoms best in culture.]

\section{DEVELOPING IS RIPENING}

a) No English example found. 
b) Kolega prezes szybko dojrzewa jako polityk.

English translation: [Our friend chairman ripens* fast as a politician.]

\section{AN ATTRACTIVE WOMAN IS A BUD}

a) No English example found.

b) Ona miała figurę gibką, liliową karnację i świeżość różowego paczka.

English translation: [She had a supple body, lilac complexion and the freshness of a pink bud].

4.2 Elaborations with Negative Denotation

DISPOSING OF UNWANTED HUMAN BEINS IS WEEDING

a) They decided to weed out unqualified applicants.

b) Musimy wyplenić dzikich plakaciarzy (..)

English translation: [We must weed out illegal people who hang posters.]

\section{PEOPLE WITH VICES ARE BAD PLANTS}

a) No English example found.

b) Paul Bernardo rozrastał się bowiem jak chwast na dobrze utrzymanym trawniku.

English translation: [Paul Bernardo was growing like a weed on the well-maintained lawn.]

\section{LOSING PHYSICAL STRENGTH IS LOSING FRESHNESS OF A PLANT}

a) And Melanie knew that she, too, had been put away in the same close airing-cupboard, this grey, tall house. Would her strength wither away?'

b) Mój ojciec powoli zanikał, wiąłł w oczach.

English translation: [My father was slowly fading, withering in my eyes.]

\section{PHYSICAL INACTIVITY IS VEGETATION}

a) Their holiday was spent is sleep and vegetation.

b) Ulka popada w ponure przewidywania wegetacji i beznadziei w przyszłej egzystencji nieskończenie długiej $\mathrm{i}$ nieskończenie nudnej.

English translation: [Ulka has dire predictions of vegetation and hopelessness in the future impossibly long and impossibly dull existence]

\section{UNHAPPY LIFE IS VEGETATION}

a) No English example found.

b) Piciem wódki próbował sobie ukrócić bolesną wegetację.

English translation: [By drinking vodka, he tried to end his painful vegetation.]

\section{Discussion and Conclusion}

Results yielded by the research undertaken in this paper prove that the source domain of PLANTS is anything but obsolete since lexemes typically assigned to it are invariably used to comprehend and represent the target domain of HUMAN BEINGS. Additionally, it was proved by means of the elaborations grouped above including NPs and VPs that the set of mappings provided in Table 1 and supplied with lexemes in English and Polish was developed properly. Furthermore, the majority of formulated elaborations be it positive or negative correspond to each other in Polish and English. More specifically, equivalents of verbs to bloom and blossom refer to a person's development in terms of beauty, profession and talent. As for negative denotations, verbs to weed out and wither accord in both 
languages. Nevertheless, despite apparent similarities between English and Polish, a number of differences can be observed. Curiously enough, some pattern can be noticed. Namely, differences pertain to English noun phrases. It is exemplified by the lexemes bud and weed, which can be mapped onto the domain of HUMAN BEINGS in Polish, but not in English. Moreover, if a mapping is possible, still it does not fully correspond in terms of meaning between languages. This is illustrated by the example with vegetation, which in both languages means inactivity, yet in Polish it also denotes an unhappy life. Clearly, these inconsistencies barely indicated by this concise study require further research. This issue is especially important in view of the fact that both speakers of Polish and English have the same deeply embedded experiential basis for formulating the metaphor A HUMAN BEING IS A PLANT, which is the life cycle of plants with all its subsequent stages that can be observed on a daily basis.

\section{References}

Aristotle. (1984). The Poetics. Translated by Ingram Bywater. New York: Modern Library.

Barcelona, A. (2002). Guidelines for the application of the theories of metaphor and metonymy to textual examples. Metaphor. A Multidisciplinary Approach. Komendziński, T. (Editor). Toruń: Wydawnictwo Uniwersytetu Mikołaja Kopernika, pp 143-175.

BYU-BNC: British National Corpus. Retrieved from http://corpus.byu.edu/bnc

Fujita, S. (1976). The Metaphor of Plant in Jewish Literature of the Intertestamental Period. Journal for the Study of Judaism, 7(1), 30-45. http://dx.doi.org/10.1163/157006376X00032

Bhutia, T. (Editor). (2015). Encyclopaedia Britannica. Retrieved from www.britannica.com/topic/Great-Chain-of-Being

Kay, P., \& Kempton, W. (1984). What is the Sapir-Whorf Hypothesis?. American Anthropologist. New Series, 86(1), 65-79.

Korpus Języka Polskiego Retrieved from PWN. http: //sjp.pwn.pl

Kövecses, Z. (2002). Metaphor. A practical introduction. Oxford: Oxford University Press.

Krzeszowski, T. P. (1997). Angels and Devils in Hell: Elements of Axiology in Semantics. Warszawa: Wydawnictwo Energeia.

Lakoff, G., \& Turner, M. (1989). More than Cool Reason. A Field Guide to Poetic Metaphor. Chicago: The University of Chicago Press.

Lakoff, G., \& Johnson, M. (1980). Metaphors We Live By. Chicago: University Press of Chicago.

Lakoff, G. (1992). The Contemporary Theory of Metaphor. Retrieved from http://terpconnect.umd.edu/ israel/lakoff-ConTheorMetaphor.pdf

Nisbet, R. (1982). Prejudices: A Philosophical Dictionary. Cambridge, Mass.: Harvard University Press.

Ricoeur, P. (1975). Between Rhetorics and Poetics: Aristotle. The Rule of Metaphor: Multidisciplinary Studies of the Creation of Meaning in Language. Toronto: University of Toronto Press.

Searle, J. (1979b). Expression and Meaning: Studies in the Theory of Speech Acts. Cambridge: Cambridge University Press.

\section{Notes}

Note 1. According to the Sapir-Whorf hypothesis discussed by Kay and Kempton (1984), our understanding of the world can be constrained by the structure of our native language.

Note 2. A cognitive domain is a primary structure which organizes and systematizes our knowledge about the world. Examples of domain are as follows: time, journey, animals, plants, etc.

Note 3. Superordiante categories are placed at the top of folk taxonomies. They have a high level of generality, whereas superordinate categories are more specific. For example, a superordinate category would be a flower, whereas subordinate - a type of flower, e.g. rose, tulip.

Note 4. The following paper focuses on the structural metaphor HUMAN BEINGS ARE PLANTS. Thus, the remaining types of metaphor: orientational and ontological are deliberately not taken into consideration as separate 
theoretical concepts. Nonetheless, they are discussed as elaborations of the basic metaphor A HUMAN BEING IS A PLANT.

Note 5. Similarly, Nisbet (1982:35) emphasizes the influence of Plato and Aristotle.

Note 6. For more information concerning the concept of frames, see Fillmore (1976) Frame semantics and the nature of language.

Note 7. For more information concerning Idealized Cognitive Models, see Lakoff (1987) Cognitive models and prototype theory.

Note 8 . In linguistics, a noun phrase is abbreviated to NP, whereas a verb phrase - to VP. 